\title{
THE IMPACT OF CURRENCY EXCHANGE RATE AND AIRCRAFT TYPE SELECTION ON INDONESIA AIRLINES BUSINESS SUSTAINABILITY
}

\author{
Muhammad Iqbal $\mathrm{L}^{\mathbf{1}}$, Kevin Dennis $\mathrm{R}^{\mathbf{2}}$, Charles $\mathrm{An}^{\mathbf{3}}$ \\ 1. STMT Trisakti Jakarta, 2. STMT Trisakti, 3. STMT Trisakti \\ $\triangle$ Corresponding author: Iqbal.liling@gmail.com
}

\begin{abstract}
Throughout the 2012-2016 the exchange rate of rupiah against the dollar depreciated or weakened that can be quite influential, US dollar was common currency in airline business fluctuating or change in currency exchange rate cannot be negligible because its impact to cost, most of the total cost of operating an airline is a plane and every aircraft has different operating costs because each aircraft have different capabilities and performance, aircraft costs that higher even slightly above the cost frontier becomes economically uncompetitive, event there are exceptions but only for very small size depend on condition and needs, aircraft type selection become very important because the size of the total operating cost of the airline depends on the type of aircraft used by the airline, it also affects the size of the profits or losses received by the airline where the sustainability and healthy or not business on the airline determined by these two factors, and because the size of the total cost of the operation determines how much the price will be charged to passengers.
\end{abstract}

Keywords: Currency Exchange, Aircraft Type, Aircraft Selection, Total Operating Cost, Sustainability

\section{Introduction}

Currency is unit of exchange that accepted and legalize in a certain country so the currency in country A cannot be use in country B, one of the factors that makes a particular country's currency unusable in another country is the difference in the value of money, the difference in the value of money can be determined by many things such as the level of national production, import, export, state income, political condition or state security, country's foreign exchange reserves, investment, etc.

Differences in the value of a currency produces a dose of comparison between one currency with another currency called currency exchange rate, currency exchange rates show the comparison of the value of other currencies with other currencies, example dollar exchange rate against the rupiah is 13.300 rupiah meaning to get 1 dollar we can exchange 13.300 rupiah, currency exchange rate can be a factor that determines the price of a goods or commodities more expensive or cheaper in a certain country. 
The currency exchange rate is play the major role in airline business, currency exchange rate play when it comes to cost, because almost all cost aspect is pay in dollar while many of revenue is on local currency, if exchange rate of dollar is increase so the cost also increase and when exchange rate of dollar decrease so the cost, impact currency exchange it also depend value of the local currency example if exchange rate of dollar is increase the impact of the increase for Singapore, Malaysia, and Indonesia is difference because of the value of the local currency is difference.

The rupiah deprecation will be hard for airline because almost all cost is in dollar for paying aircraft, insurance, ground handling, crew, maintenance, spare part, fuel, etc. The primary currency that use in airline business is dollar, making the slight change in dollar price toward rupiah can change the cost, making the cost of airline business fluctuate depend on price of dollar toward rupiah.

Went the cost is high the ticket price and business strategy of the airline will play it is role to overcome the cost, to determine the ticket price many factor should be considerate because every route, every schedule, every season have difference market share and segmentation, also time, capacity of aircraft, aircraft performance, distance, competitor, and others should be consider, many airlines cannot adapt to changing conditions especially changes caused by changes in currency rates and competition was close.

In this condition apart from managerial and business, the aircraft's capabilities and performance also participate in influencing airline's ability to adapt and to compete, each aircraft has different capabilities and performance such as passenger capacity, payload, flight endurance, fuel consumption, crew member, maintenance cost, lifetime, etc., many of the airlines that stopped operating were caused by the use of aircraft that did not fit both in terms of business and operations and the airline's ability to get a more efficient aircraft or in accordance with the needs of the operation.

In this case we can take some of the problems we can take, first how the exchange rate affects the expenses on the airline business, secondly how 
much the changes are caused by the exchange rate, and the third how the selection of the aircraft that suits the needs can affect the success an airline in adapting to fluctuations caused by the exchange rate. To analyze and answer the existing problems the studies that we will use are quantitative studies.

\section{Method}

This study aims to search and find answers to the influence of currency exchange rate to aviation business and the impact caused by, we conduct the study by doing interpretation, analysis, and compare the data data obtained either obtained from other sources and data that have been processed by we based on the relevant theory and research which have been done before, we also look for theoretical foundations that can support the opinions and conclusions that we make.

To study the impact of changes in the exchange rate of the dollar against the rupiah against aviation business we have observed the exchange rate in 2012 - 2016 to obtain a comparative rate of exchange rate changes as a basis for comparison in observing the change of expenditures of an airline, the price of fuel and comparison operating expenses of a certain type of aircraft at different rates of exchange rates.

In order to study the effect of currency exchange changes on the use of certain aircraft, we analyze and compare the operating costs of each aircraft in different currency exchange conditions and under adjustable cost conditions, To calculate the total operating cost of each aircraft or total operating cost (TOC) according to Air Transportation A Management Perspective in determining cost there are two types of cost, Direct operating cost (DOC) expenses effected with and dependent on the type of aircraft being operated and Indirect operating Costs (IOC) costs that will remain unaffected by aircraft type because they are not directly came from aircraft operations.(Wensveen, 2007) 


\section{Discussion and Result}

Throughout the 2012-2016 the exchange rate of rupiah against the dollar depreciated or weakened that can be quite influential (See Fig.1), especially in the year 2012 - 2015 currency exchange rate decreased around $11.42 \%$ - 13.65\% more precisely in 2013 rupiah value against dollar decreased $11.42 \%$ from 9,427 decreased to 10,504 in 2014 the rupiah value decreased $13.65 \%$ from 10,504 decreased to 11,938 and last at 2015 rupiah value against dollar decreased $12.74 \%$ from 11,938 decreased to 13,459 , in 2016 the rupiah strengthened less than $0.64 \%$ from 13.459 increase to 13.374 .

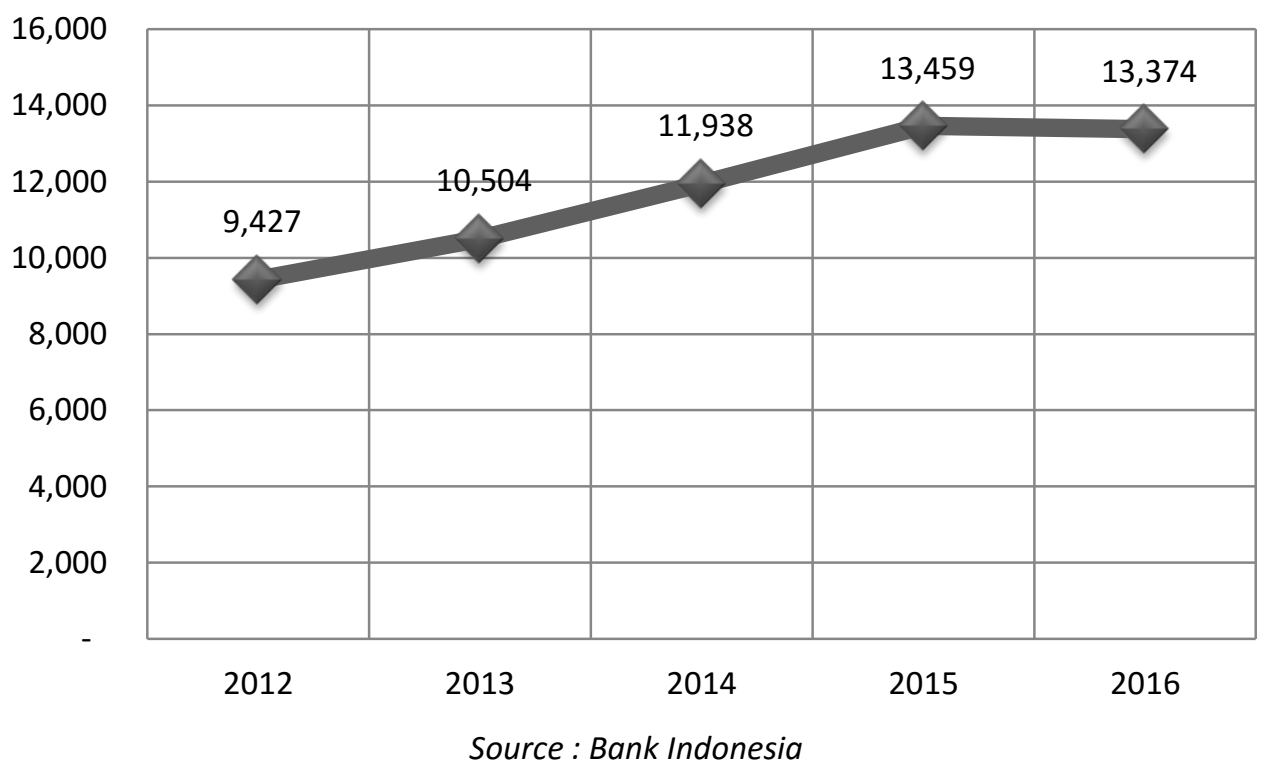

Figure 1. IDR Currency Exchange rate 2012 - 2016

Base on journal "Cost competitiveness of major airlines: an international comparison" the common currency in airline business was US dollar and it was common practice to compare their operating result in term of common currency, however fluctuating or change in currency exchange rate was cannot be negligible, because its impact on inter country cost differential, so if dollar is increase so the cost also increase and when exchange rate of dollar decrease so the cost, But it also depend our local currency value, the currency exchange rate and currency value is also applied to income because the currency exchange rate and value of the 
local currency effect the country economy and the buyer power of the passenger, also currency exchange rate played important part in market competition. (Oum \& Yu, 1998)

From 2012 - 2016 price of fuel has decreased very significantly (See Fig.2), the price of fuel is needed to calculate cost of aircraft operation because fuel is a major component in aircraft operating costs where nearly $50 \%$ of total aircraft operating costs may come from fuel, also the distance tariff or price per distance is also adjusted to factors such the fluctuation of fuel prices, the fluctuation of the fuel price may happen because the price of fuel can change depend on price at world market or company policy, at 2012 and 2013 the average price of fuel at soekarno hatta airport is 110.39 US Cent and 103.43 US cent below the average price at world market while at 2016 the average price at soekarno hatta airport is 60.71 US Cent higher than average price of world market, the fluctuation on fuel price could be an opportunity for airlines but the decline of the rupiah exchange rate against the dollar causes the opportunities and benefits received by the airline from the decline in fuel prices may not optimal. (Ricardianto, Djajaputra, \& Martono,

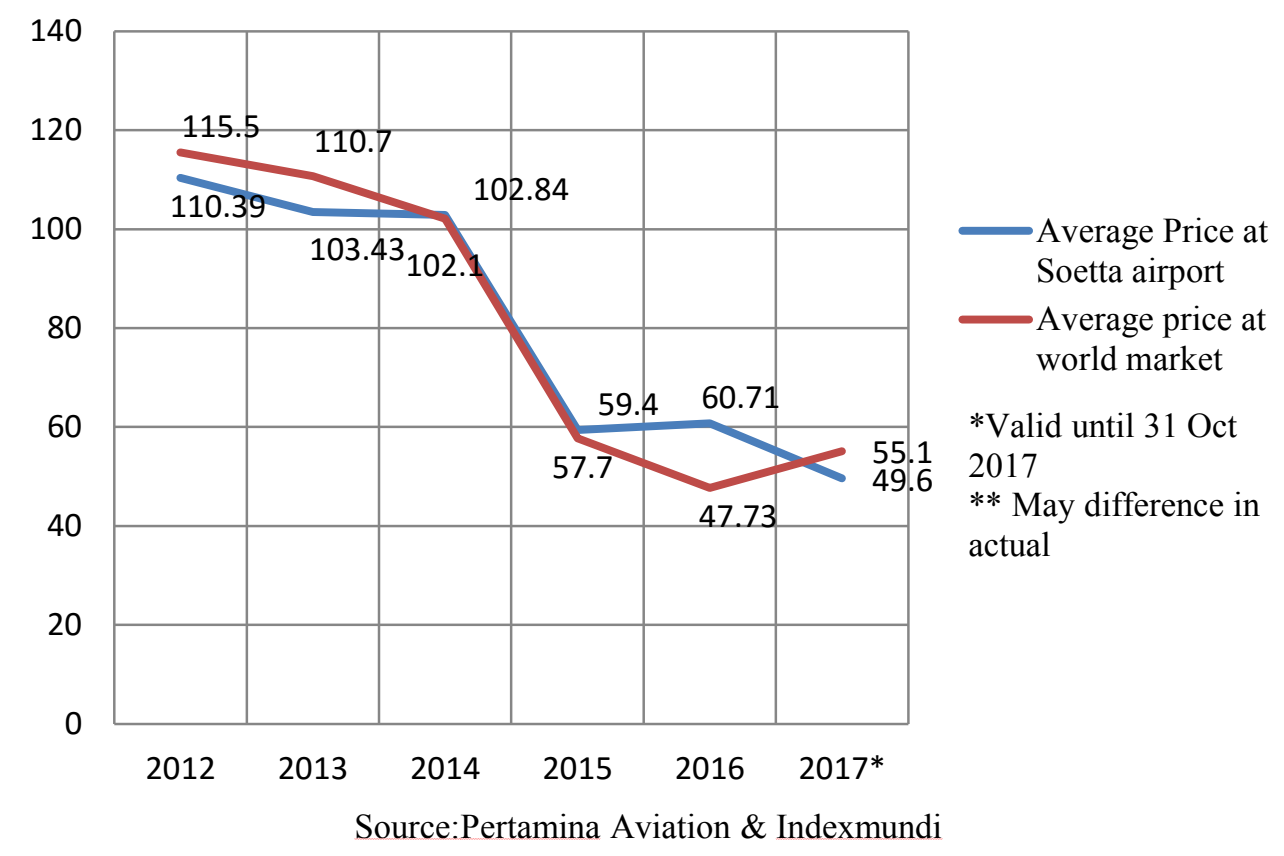

Figure 2. Fuel price in US Cent / liter 2012 - 2016 
Effects and impacts caused by the exchange rate on the aviation business one can be seen from the size of the profits or losses received by an airline, the amount of profit or loss is affected by the ratio between income and total operating costs of an airline, most of the total cost of operating an airline is a plane and every aircraft has different operating costs because each aircraft have different capabilities and performance such as passenger capacity, payload, flight endurance, fuel consumption, crew member, maintenance cost, lifetime, etc., base on journal The Impact of Fuel Increase and Currency Exchange Depreciation on Indonesia Aviation Industry Sustainability we calculate the total operating cost (TOC) as in table 1, and 2. (Simarmata, Charles An, \& Rizaldy, 2014)

Table 1. Cost structure comparison between Boeing 737 \& Airbus A320 Family at 2012

\begin{tabular}{|c|c|c|c|c|c|c|}
\hline Description & $\begin{array}{c}200 \mathrm{Hrs} \\
\text { cost/ Hrs } \\
\text { USD }\end{array}$ & $\begin{array}{c}200 \mathrm{Hrs} \\
\text { cost/ Hrs } \\
\text { USD }\end{array}$ & $\begin{array}{c}200 \mathrm{Hrs} \\
\text { cost/ Hrs } \\
\text { USD }\end{array}$ & $\begin{array}{c}200 \mathrm{Hrs} \\
\text { cost/ Hrs } \\
\text { USD }\end{array}$ & $\begin{array}{c}200 \mathrm{Hrs} \\
\text { cost/ Hrs } \\
\text { USD }\end{array}$ & $\begin{array}{c}200 \mathrm{Hrs} \\
\text { cost/ Hrs } \\
\text { USD }\end{array}$ \\
\hline $\begin{array}{c}\text { DIRECT } \\
\text { OPERATING } \\
\text { COST }\end{array}$ & В 735 & B $377 \mathrm{~W}$ & B $738 \mathrm{~W}$ & B $739 \mathrm{~W}$ & A 319 & A 320 \\
\hline AIRCRAFT & 445.00 & $1,755.00$ & $1,250.00$ & $2,250.00$ & $1,075.00$ & $1,100.00$ \\
\hline CREW & 202.16 & 260.19 & 260.19 & 260.19 & 280.23 & 280.23 \\
\hline MAINTENANCE & $1,255.00$ & 843.00 & 920.00 & 964.00 & $1,001.00$ & $1,070.00$ \\
\hline INSURANCE & 233.33 & 317.03 & 416.67 & 416.67 & 364.58 & 375.00 \\
\hline FUEL & $3,587.67$ & $3,131.32$ & $3,492.96$ & $3,790.02$ & $3,217.43$ & $3,434.34$ \\
\hline $\begin{array}{c}\text { ROUTE } \\
\text { NAV.FEE }\end{array}$ & 139.76 & 146.26 & 167.93 & 173.35 & 173.35 & 178.76 \\
\hline LANDING FEE & 22.18 & 22.18 & 32.32 & 35.36 & 36.37 & 40.43 \\
\hline PARKING FEE & 27.45 & 27.45 & 31.95 & 33.30 & 33.75 & 35.55 \\
\hline $\begin{array}{c}\text { GROUND } \\
\text { HANDLING }\end{array}$ & 67.50 & 112.50 & 112.50 & 112.50 & 131.25 & 131.25 \\
\hline $\begin{array}{c}\text { CREW } \\
\text { TRAINING }\end{array}$ & 9.08 & 13.27 & 13.27 & 13.27 & 16.59 & 16.59 \\
\hline CATERING & 99.00 & 111.75 & 141.75 & 144.00 & 108.75 & 130.50 \\
\hline SUB TOTAL & $6,088.13$ & $6,739.95$ & $6,839.54$ & $8,192.66$ & $6,438.30$ & $6,792.65$ \\
\hline $\begin{array}{c}\text { INDIRECT } \\
\text { OPEARTING } \\
\text { COST }\end{array}$ & 608.81 & 674.00 & 683.95 & 819.27 & 643.83 & 679.26 \\
\hline DOC x $10 \%$ & & & & & & \\
\hline
\end{tabular}


Table 1, Cont. Cost structure comparison between Boeing 737 \& Airbus A320 Family at 2012

\begin{tabular}{|c|c|c|c|c|c|c|}
\hline \multicolumn{7}{|c|}{ TOTAL OPERATING COST } \\
\hline IN USD & $6,696.94$ & $7,413.95$ & $7,523.50$ & $9,011.93$ & $7,082.13$ & $7,471.91$ \\
\hline $\begin{array}{c}\text { IN IDR } \\
(.000)\end{array}$ & 63,132 & 69,891 & 70,924 & 84,955 & 66,763 & 70,437 \\
\hline $\begin{array}{c}\text { TOC/SEAT } \\
\text { HOURS }\end{array}$ & 51.51 & 49.76 & 39.81 & 41.92 & 48.51 & 42.94 \\
\hline MARGIN 10\% & 669.69 & 741.39 & 752.35 & 901.19 & 708.21 & 747.19 \\
\hline $\begin{array}{c}\text { SELLING PRICE/ } \\
\text { HOUR }\end{array}$ & $7,366.64$ & $8,155.34$ & $8,275.85$ & $9,913.12$ & $7,790.34$ & $8,219.10$ \\
\hline $\begin{array}{c}\text { SELLING PRICE/ } \\
\text { SEAT HOUR }\end{array}$ & 56.67 & 54.73 & 43.79 & 46.11 & 53.36 & 47.24 \\
\hline $\begin{array}{c}\text { PERCENTAGES } \\
\text { OF FUEL COST }\end{array}$ & $53.57 \%$ & $42.24 \%$ & $46.43 \%$ & $42.06 \%$ & $45.43 \%$ & $45.96 \%$ \\
\hline
\end{tabular}

Source: The Impact of Fuel Increase and Currency Exchange Depreciation on Indonesia Aviation Industry Sustainability

Table 2. Cost structure comparison between Boeing 737 \& Airbus A320 Family at 2016

\begin{tabular}{|c|c|c|c|c|c|c|}
\hline Description & $\begin{array}{c}200 \mathrm{Hrs} \\
\text { cost/ Hrs } \\
\text { USD }\end{array}$ & $\begin{array}{c}200 \mathrm{Hrs} \\
\text { cost/ Hrs } \\
\text { USD }\end{array}$ & $\begin{array}{c}200 \mathrm{Hrs} \\
\text { cost/ Hrs } \\
\text { USD }\end{array}$ & $\begin{array}{c}200 \mathrm{Hrs} \\
\text { cost/ Hrs } \\
\text { USD }\end{array}$ & $\begin{array}{c}200 \mathrm{Hrs} \\
\text { cost/ Hrs } \\
\text { USD }\end{array}$ & $\begin{array}{c}200 \mathrm{Hrs} \\
\text { cost/ Hrs } \\
\text { USD }\end{array}$ \\
\hline $\begin{array}{c}\text { DIRECT } \\
\text { OPERATING } \\
\text { COST }\end{array}$ & B 735 & B 377 W & B 738 W & B 739 W & A 319 & A 320 \\
\hline AIRCRAFT & 445.00 & $1,755.00$ & $1,250.00$ & $2,250.00$ & $1,075.00$ & $1,100.00$ \\
\hline CREW & 202.16 & 260.19 & 260.19 & 260.19 & 280.23 & 280.23 \\
\hline MAINTENANCE & $1,255.00$ & 843.00 & 920.00 & 964.00 & $1,001.00$ & $1,070.00$ \\
\hline INSURANCE & 233.33 & 317.03 & 416.67 & 416.67 & 364.58 & 375.00 \\
\hline FUEL & $1,973.08$ & $1,722.10$ & $1,920.99$ & $2,084.36$ & $1,769.45$ & $1,888.74$ \\
\hline ROUTE NAV.FEE & 139.76 & 146.26 & 167.93 & 173.35 & 173.35 & 178.76 \\
\hline LANDING FEE & 22.18 & 22.18 & 32.32 & 35.36 & 36.37 & 40.43 \\
\hline PARKING FEE & 27.45 & 27.45 & 31.95 & 33.30 & 33.75 & 35.55 \\
\hline $\begin{array}{c}\text { GROUND } \\
\text { HANDLING }\end{array}$ & 67.50 & 112.50 & 112.50 & 112.50 & 131.25 & 131.25 \\
\hline $\begin{array}{c}\text { CREW } \\
\text { TRAINING }\end{array}$ & 9.08 & 13.27 & 13.27 & 13.27 & 16.59 & 16.59 \\
\hline CATERING & 99.00 & 111.75 & 141.75 & 144.00 & 108.75 & 130.50 \\
\hline
\end{tabular}


Table 2, Cont. Cost structure comparison between Boeing 737 \& Airbus A320 Family at 2016

\begin{tabular}{|c|c|c|c|c|c|c|}
\hline SUB TOTAL & $\begin{array}{c}4,473.5 \\
4 \\
\end{array}$ & $5,330.73$ & $5,267.57$ & $6,487.00$ & $4,990.32$ & $5,247.05$ \\
\hline $\begin{array}{c}\text { INDIRECT } \\
\text { OPERATING } \\
\text { COST }\end{array}$ & \multirow[t]{2}{*}{447.35} & \multirow[t]{2}{*}{533.07} & \multirow[t]{2}{*}{526.76} & \multirow[t]{2}{*}{648.70} & \multirow[t]{2}{*}{499.03} & \multirow[t]{2}{*}{524.71} \\
\hline DOC x 10\% & & & & & & \\
\hline \multicolumn{7}{|c|}{ TOTAL OPERATING COST } \\
\hline IN USD & $4,920.89$ & $5,863.80$ & $5,794.32$ & $7,135.70$ & $5,489.36$ & $5,771.76$ \\
\hline IN IDR & $\begin{array}{c}65,812,03 \\
6\end{array}$ & $\begin{array}{c}78,422,5 \\
03\end{array}$ & $\begin{array}{c}77,493,2 \\
99\end{array}$ & $\begin{array}{c}95,432,8 \\
17\end{array}$ & $\begin{array}{c}73,414,6 \\
50\end{array}$ & $\begin{array}{c}77,191,5 \\
16\end{array}$ \\
\hline $\begin{array}{l}\text { TOC/SEAT } \\
\text { HOURS }\end{array}$ & 37.85 & 39.35 & 30.66 & 33.19 & 37.60 & 33.17 \\
\hline MARGIN 10\% & 492.09 & 586.38 & 579.43 & 713.57 & 548.94 & 577.18 \\
\hline $\begin{array}{c}\text { SELLING } \\
\text { PRICE/ HOUR }\end{array}$ & $5,412.98$ & $6,450.18$ & $6,373.76$ & $7,849.27$ & $6,038.29$ & $6,348.94$ \\
\hline $\begin{array}{c}\text { SELLING } \\
\text { PRICE/ SEAT } \\
\text { HOUR }\end{array}$ & 41.64 & 43.29 & 33.72 & 36.51 & 41.36 & 36.49 \\
\hline $\begin{array}{c}\text { PERCENTAG } \\
\text { ES OF FUEL } \\
\text { COST }\end{array}$ & $40.10 \%$ & $29.37 \%$ & $33.15 \%$ & $29.21 \%$ & $32.23 \%$ & $32.72 \%$ \\
\hline
\end{tabular}

Source: The Impact of Fuel Increase and Currency Exchange Depreciation on Indonesia Aviation Industry Sustainability

In tables 1 , and 2 it show that operating costs of each aircraft difference, the cause of the difference in operating costs of an aircraft is caused by the difference in the ability and performance such as weight, fuel, maintenance of the aircraft also the need for the aircraft to operate is different, aircraft costs that higher even slightly above the cost frontier becomes economically uncompetitive, event there are exceptions but only for very small size depend on condition and needs (Swan \& Adler, 2006), for example we compare the cost between Boeing 737 - 800 or 738 with Airbus A320 that has a capacity of 189 passengers with a maximum payload of 20.5 tons and A320 with 174 with a maximum payload of 16.5 tons, we can see the cost of the use of aircraft, insurance, fuel, catering, crew training from B738is slightly higher than A320 while the cost of crew, maintenance, ground handling, navigation and airport service fee of A320 is higher than B738. 
From table 1 and 2 of the decline in the fuel price have an enormous impact on the continuity of operations of a company and participate in the decrease in total operating costs, the fuel price decrease from 110.39 US Cent in 2012to 60.71 US Cent in 2016, in table 1 the total operating cost for the B738 in 2012 was USD 7,523.50 with $46.43 \%$ coming from fuel while in table 2 the total cost of B738 operations in 2016 was USD 5,794.32 with $33.15 \%$ comes from fuel, from 2012 to 2016 there is a decrease in total operating cost of USD 1729.18 or $22.98 \%$ and the impact of fuel to cost of 13.28\%.(Simarmata, Charles An, \& Rizaldy, 2014)

By using table 1 or 2 we can see total operating cost for B738 aircraft in 2012 when fuel price at 110.39 Cent US and exchange rate of rupiah is at 9,427., the total operating cost was USD 7,523.50 or IDR 70,924,022 compare in 2016 total operating cost B738 is USD 5,794.32 or IDR $77,493,299$., or we can assume if the total operating cost of B738 aircraft in 2012 and 2016 is equal USD 5,794.32 then in 2012 the total operating cost is IDR 54,623,054 and 2016 IDR 77,493,299., with these two equations we can see that increase of exchange rate indirectly cause increase not only to cost but also price, but the decline in fuel prices suppress the rising costs caused by the currency exchange rate and become opportunity to airlines.

In this conditions aircraft type selection become very important because the size of the total operating cost of the airline depends on the type of aircraft used by the airline, it also affects the size of the profits or losses received by the airline where the sustainability and healthy or not business on the airline determined by these two factors, and because the size of the total cost of the operation determines how much the price will be charged to passengers, for example the selling price of the B735 is 41.64 , the B738 is 33.72 and the A320 is 41.36 , from three aircraft on same route, the selling price of B738 is lower and more competitive compared to the use of B735 and A320, selling price is important because price is considered as one of the important factors when passengers making decision to use or buy service which in the end will also determine our income. (Simarmata, Charles An, \& Rizaldy, 2014) (Simarmata, Rs, Keke, \& Panjaitan, 2016) 
Aircraft type or fleet mix decisions such as the size of the aircraft and the number of aircraft type use in the fleet have impact in terms of technical and cost efficiency, because each aircraft has different capabilities and performance as well as the airport, although using the B738 aircraft does not mean total operating costs are small or the profits is greater, the airline should pay attention to the size of the demand for a route (Merkert \& Hensher, 2011), and take into account the conditions of the airport and other support infrastructure which enable the process of fulfill their needs such as runway length, runway slope, runway strength, navigation facility, availability of GSE, etc., This is important because despite the large number of demand but the aircraft used is not suitable it can cause an airline to loss. (Simarmata, Yuliantini, \& Keke, 2017)

\section{Conclusion}

As the common currency dollar becomes the main currency in the airline business where almost all the cost is calculated based on the dollar making the slight change in the dollar price toward the rupiah can change the cost, making the cost of airline business fluctuate depend on the price of dollar to the rupiah, which in five the last year the exchange rate of rupiah against the dollar has increased significantly, especially in 2014 it was difficult year for airline business where the exchange rate has increased quite high and the relatively high fuel prices forced the airline to ticket prices to cover operating costs and at the same time have to compete with other airlines.

Under these circumstances the airline's planning and strategy is very influential in the airline's ability to survive and compete, taking into account the size of the demand as well as the capabilities and availability of supporting facilities for airline operations the airlines can know which aircraft are suitable for their needs, and what is financial target such as projected income, cost, and profit, as the appropriate use of aircraft can minimize operating costs and total costs which is charged by airlines, many airlines are closed due to inappropriate use of aircraft and also the use of 
older aircraft may not necessarily cause the airline to lose money or bankrupt. (Simarmata \& Charles AN, n.d.)

In addition, fuel conservation is the strategy should be applied by the airlines in order to continue to compete within dollar exchange rate fluctuations because almost $50 \%$ of Total operating cost of aircraft came from fuel, by decreasing use of fuel will lower the total operating cost and the use of cost index, tankering fuel from base that have lower fuel price, optimum flight level elections, focusing on flight performance, and carry the reasonable amount of trip fuel can improve the efficiency in the use of fuel during the flight so it is able to decreasing the total operating costs. (Simarmata, Charles An, \& Rizaldy, 2014)

\section{References}

Merkert, R., \& Hensher, D. A. (2011). The impact of strategic management and fleet planning on airline efficiency - A random effects Tobit model based on DEA efficiency scores. Transportation Research Part A, 45(7), 686-695. https://doi.org/10.1016/j.tra.2011.04.015

Oum, T. H., \& Yu, C. (1998). Cost competitiveness of major airlines: an international comparison. Transportation Research Part A, 32(6), 407422. https://doi.org/10.1016/S0965-8564(98)00007-X

Ricardianto, I. P., Djajaputra, D. G., \& Martono, P. D. (2017). Air Transport and Tourism in Indonesia. IOSR Journal of Applied Chemistry, 10(5), 01-19. https://doi.org/10.9790/5736-1005010119

Simarmata, J., \& Charles AN. (n.d.). Analysis and Evaluation on the Strategy of Indonesian Airline Companies to Face the Increasing Price of Avtur and the Decreasing Exchange Value of Rupiah against the US Dollar Juliater, (2), 1-16. Retrieved from http://www.dpu.ac.th/masean/upload/content/files/019 Analysis and Evaluation on the Strategy of Indonesian Airline Companies.pdf

Simarmata, J., Charles An, \& Rizaldy, W. (2014). The Impact of Fuel Increase and Currency Exchange Depreciation on Indonesia Aviation Industry Sustainability. Jurnal Manajemen Transportasi \& Logistik (JMTransLog) -, 1(3), 199-208. Retrieved from http://ejournal.stmttrisakti.ac.id/index.php/JMTRANSLOG/article/view/18

Simarmata, J., Rs, M., Keke, Y., \& Panjaitan, F. (2016). the Airline Customer'S Buying Decision Through Online Travel Agent: a Case Study of the Passengers of Scheduled Domestic Airlines in Indonesia. International Journal of Economics, Commerce and Management United Kingdom, 3(3), 335-349. Retrieved from http://ijecm.co.uk/

Simarmata, J., Yuliantini, Y., \& Keke, Y. (2017). The Influence of Travel Agent, Infrastructure and Accommodation on Tourist Satisfaction. In 
Proceedings of the International Conference on Tourism, Gastronomy, and Tourist Destination (ICTGTD 2016) (Vol. 28, pp. 281-283). Paris, France: Atlantis Press. https://doi.org/10.2991/ictgtd-16.2017.55

Swan, W. M., \& Adler, N. (2006). Aircraft trip cost parameters : A function of stage length and seat capacity, 42, 105-115. https://doi.org/10.1016/j.tre.2005.09.004

Wensveen, J. G. (2007). Air Transportation A Management Perspective (Sixth Edit). Oxfordshire: Ashgate Publishing Limited. 